a homoeostatic mechanism whereby the vasospastic and platelet aggregatory actions of thromboxane $\mathrm{A}_{2}$ are attenuated. These results provide a rationale for evaluating treatment that inhibits thromboxane $A_{2}$ while preserving the synthesis of prostacyclin.

This study was supported by a grant (HL 30400) from the National Institutes of Health. LR was supported in part by grants from the Quebec Heart Foundation and the Tennessee Affiliate of the American Heart Association. GAF is an established investigator for the American Heart Association.

\section{References}

1 Freedman RR, Ianni P. The role of cold and emotional stress in Raynaud's disease and scleroderma. Br.Med f 1983:287: 1499-502.

2 Rodnan GP, Myerowitz RL. Justh GO. Morphologic changes in the digital arteries of patients with progressive systemic sclerosis (scleroderma and Ravnaud's phenomenon. Medicine with progressive systemic
Baltimore 1980;59:393-407.

3 Lerov EC. Pathogenesis of scleroderma (svstemic sclerosis . F Invest Dermatol 1982;79:87-9.

4 Halpern A, Kuhn PH, Shaftel HE, et al. Raynaud's disease. Ravnaud's phenomenon and serotonin. Angiology 1960;11:151-67.

5 Hamberg M. Svensson J, Samuelsson B. Thromboxanes: a new group of biologically active compounds derived from prostaglandin endoperoxides. Proc Natl Acad Sci USA 1975;72 2994-8

6 Needleman P. Raz R, Ferrendelli JA, Minkes M. Application of imidazole as a selective inhibito of thromboxane synthetase in human platelets. Proc Nall Acad Sci USA 1977;74:1716-20.

7 Jones RL, Wilson NH, Armstrong RA, Peesapati V, Smith GM. Effects of the thromboxane antagonist EP045 on platelet aggregation. Adv Prostaglandin Thromboxane Leukotriene Res $1983: 11: 345-50$

8 American Rheumatism Association. Preliminary criteria for the classification of systemic sclerosis scleroderma). Arthritis Rheum 1980;23:581-90.

9 Lawson JA, Brash AR, Doran J, FitzGerald GA. Measurement of urinary 2,3-dinor-thromboxane $B_{2}$ and thromboxane $B_{2}$ using bonded phase phenyl boronic acid columns and capillary gas $\mathrm{B}_{2}$ and $\mathrm{B}$ ra $463-70$.

10 FitzGerald GA, Lawson JA, Blair IA, Brash AR. Analvsis of urinary metabolites of thromboxane and prostacyclin by negative ion-chemical ionization gas chromatography-mass spectrometry. Advances in Prostaglandin Thromboxane and Leukotriene Research 1985;15:87-90.

11 Patrono C, Ciabattoni G, Pinca E, et al. Low dose aspirin and inhibition of thromboxane $\mathrm{B}_{2}$ production in healthy subjects. Thromb Res 1980;17:317-27.

12 Born GVR. Aggregation of blood platelets by adenosine diphosphate and its reversal. Nature 1962;194:927-9.

13 Luderer JR, Nicholas GG, Neumyer MM, et al. Dazoxiben, a thromboxane synthetase inhibitor, in Raynaud's phenomenon. Clin Pharmacol Ther 1984;36:105-15.
14 Belch JJF, Cormie J, Newman P, et al. Dazoxiben, a thromboxane synthetase inhibitor, in the treatment of Raynaud's syndrome: a double blind trial. Br f Clin Pharmacol 1983;15:113-6.

15 Hirsh PD, Hillis LD, Campbell WB, Firth BG, Willerson JT. Release of prostaglandins and thromboxane into the coronary circulation in patients with ischemic heart disease. $N \mathrm{Engl}$. Med 1981;304:685-91

16 Patrono C, Ciabattoni G, Pugliese F, Peirucci A, Blair IA, FitzGerald GA. Estimated rate of thromboxane secretion into the circulation of normal man. 7 Clin Invest 1986;77:590-4.

17 Ruberts LJ, Sweetman BJ, Oates JA. Metabolism of thromboxane $\mathbf{B}_{2}$ in man: identification of twenty metabolites. 7 Biol Chem 1981;256:8384-93.

18 FitzGerald GA, Pedersen AK. Patrono C. Analysis of prostacyclin and thromboxane $A_{2}$ biosvnthesis in cardiovascular disease. Circulation 1983;67:1174-7.

19 Reilly IAG, Doran J, Smith B, FizGerald GA. Increased thromboxane biosynthesis in a human model of platelet activation: biochemical and functional consequences of selective inhibition of thromboxane synthase. Circulation (in press

20 Fitzgerald DJ, Roy LR, FitzGerald GA. Enhanced prostacyclin and thromboxane $\mathrm{A}_{2}$ synthesis in ischemic heart disease: non-invasive evidence of sporadic platelet activation in unstable angina. Circulation 1985;72:1688

21 FitzGerald GA. Brash AR, Falardeau P, Oates JA. Estimated rate of prostacyclin secretion into the circulation of normal man. $\mathcal{F}$ Clin Invest 1981;68:1272-5.

22 Rov L, Knapp H, Robertson RM, FitzGerald GA. Endogenous biosvnthesis of prostacyclin during cardiac catheterization and angiography in man. Circulation 1985;71:434-9.

23 FitzGerald GA, Smith B, Pedersen AK, Brash AR. Increased prostacyclin biosynthesis in patients with severe atherosclerosis and platelet activation. N Engl f Med 1984:310:1065-8.

24 Nowak J. Murray JJ, Oates JA, FitzGerald GA. Platelet function and the in vivo formation of thromboxane $\dot{A}_{2}$ and prostacyclin during chronic smoking and withdrawal in man [Abstract]. Thromb Hemost 1985;54:1029.

$25 \mathrm{Kaplan} \mathrm{KL}$. Owen J. Plasma levels of $;$;-thromboglobulin and platelet factor 4 as indices of platele activation in vivo. Blood 1981:47:199-202.

26 Zahavi J, Hamilton WAP, O'Reilly MJG, Levton J, Cotton LT, Kakkar WV. Plasma exchange and platelet function in Raynaud's phenomenon. Thromb Res 1980;19:85-93.

27 Kahaleh MB, Osborn I, Leroy EC. Elevated levels of circulating platelet aggregates and $\beta$ thromboglobulin in scleroderma. Ann Intern Med 1982;96:610-3.

28 Ettinger WH, Wise RR. Schaffhauser D, Wigley FM. Controlled double-blind trial of dazoxiben and nifedipine in the treatment of Raynaud's phenomenon. Am J Med 1984:77:451-6.

Coffman JD, Rasmussen HM. Effect of thromboxane synthetase inhibition in Raynaud's phenomenon. Clin Pharmacol Ther 1984:36:369-73.

30 Jones EW, Hawkev CJ. A thromboxane synthetase inhibitor in Ravnaud's phenomenon Prostaglandins Leukotrienes Med 1983;12:67-71.

31 Bertele V, de Gaetano G. Potentiation by dazoxiben, a thromboxane sunthetase inhibitor, of platelet aggregation inhibitory activity of a thromboxane receptor antagonist and of prostacvclin. Eur 7 Pharmacol 1982:85:331-3.

32 FitzGerald GA. Reilly IAG, Pedersen AK. The biochemical pharmacology of thromboxane svnthase inhibition in man. Circulation 1985:72:1194-201.

33 Fitzgerald DJ, Fragetta JE, Jackson EK. FitzGerald GA. Prostaglandin endoperoxides limit the platelet inhibitory effects of thromboxane svnthase inhibitors in vivo. Clin Res 1985;33:282.

34 Di Minno G, Silver MJ, Murphy S. Monitoring the entry of new platelets into the circulation after ingestion of aspirin. Blood 1983;61:1081-5.

35 FitzGerald GA. Oates JA. Hawiger J, et al. Endogenous biosynthesis of prostacyclin and thromboxane and platelet function during chronic administration of aspirin in man. $7 \mathrm{Clin}$ Invest 1983;71:676-88.

Accepted 6 February 1986

\title{
Screening for intrauterine growth retardation using ratio of mid-arm circumference to occipitofrontal circumference
}

\author{
N J MEADOWS, J TILL, A LEAF, E HUGHES, B JANI, V LARCHER
}

\begin{abstract}
Uncritical application of standard weight percentile charts, derived from white infants, to infants from different ethnic groups may result in an overestimate of the incidence of intrauterine growth retardation in those groups. The ratio of mid-arm circumference to occipitofrontal circumference was studied in 194 babies (49 Asian, 58 black, and 87 white). In contrast with birth weight the ratio did not vary among the ethnic groups; it was also independent of sex. In a prospective study of
\end{abstract}

Department of Child Health, Salvation Army, Mothers' Hospital, London E5 N J MEADOWS, MB, MRCP, lecturer

J TILL, MB, BSC, senior house officer

A LEAF, MB, MRCP, senior house officer

E HUGHES, MB, MRCP, senior house officer

$B$ JANI, $M B, D C H$, senior house officer

V LARCHER, MB, MRCP, consultant paediatrician

Correspondence to: Dr N J Meadows, Queen Elizabeth Hospital for Children, London E2 8PS
64 neonates whose weight was below the 10th percentile on standard charts the ratio of mid-arm circumference to occipitofrontal circumference was a more accurate predictor than weight of those infants who would develop symptoms associated with intrauterine growth retardation.

The ratio of mid-arm circumference to occipitofrontal circumference therefore provides a simple, accurate, and cheap way of assessing intrauterine growth retardation in areas with a large multiethnic population, where birth weight varies greatly.

\section{Introduction}

The mean birth weight of white infants differs from that of infants born to mothers from other ethnic groups, especially Asian. ${ }^{1.3}$ Because established percentile charts relate to white infants, the criterion of weight alone cannot be used to identify accurately intrauterine growth retardation in infants from other ethnic groups. We measured the ratio of mid-arm circumference to occipitofrontal circumference in normal full term babies from different ethnic 
groups to define a normal range and to determine whether a decreased ratio could be used as a screening test to identify intrauterine growth retardation.

\section{Subjects and methods}

All infants studied were judged full term on the basis of the Parkin score, performed in the first 24 hours of life. The birth weight and ethnic group were recorded. The study was carried out over two periods of three months In the first three months the mid-arm circumference and occipitofrontal circumference were measured on the third day of life of all babies admitted to the postnatal wards. Measurements were taken with a non-stretch plastic tape measure. The mid-arm circumference was taken at the point halfway between the acromion and the olecranon process of the ulna on the right arm, which was flexed at $90^{\circ}$. The occipitofrontal circumference was taken as the largest circumference of the skull. The coefficient of variation of the method, assessed by making 10 measurements of one child on the same day, was found to be $2 \cdot 0 \%$. The interobserver coefficient of variation (four observers each made 10 measurements of the same child) was $2 \cdot 5 \%$. A mean ratio for each ethnic group was determined and abnormal values defined as those that varied from the mean by $>2$ SD. Data were compared by Student's $t$ test. During the second study only those infants whose birth weight fell below the 10th percentile on the charts derived by Gairdner were measured. Clinical symptoms were recorded, together with any correlation between them and an abnormal ratio of mid-arm circumference to occipitofrontal circumference.

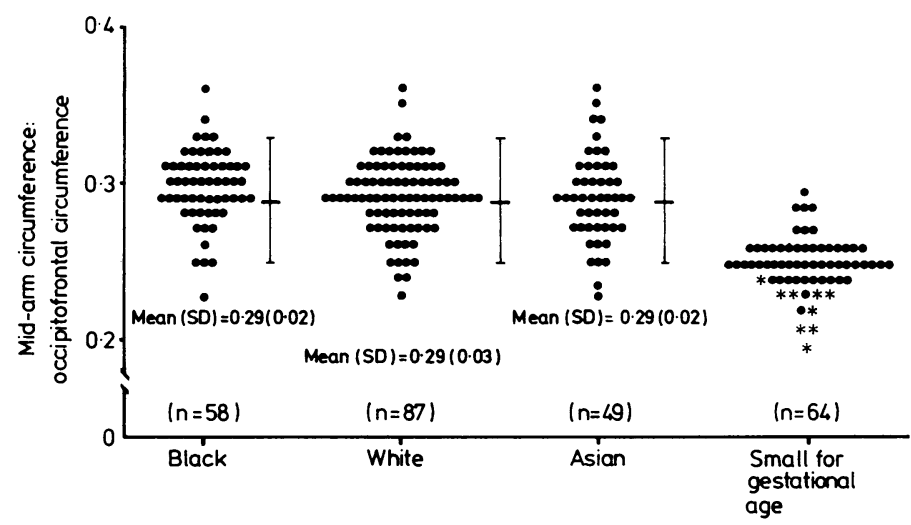

Ratio of mid-arm circumference to occipitofrontal circumference in ethnic groups and all infants small for gestational age.

$\star$ Symptomatic infants.

\section{Results}

The mean birth weights of the three ethnic groups showed no significant difference (black 3090 (SD 440) $\mathrm{g}(\mathrm{n}=58)$; white 3180 (510) $\mathrm{g}(\mathrm{n}=87)$; Asian $\stackrel{\Phi}{\circ}$ $2900(360) \mathrm{g}(\mathrm{n}=49))$, but seven black (12\%), six white $(7 \%)$, and 10 Asian $\mathrm{C}$ $(20 \%)$ babies had birth weights below the 10th percentile, suggesting that a higher proportion of Asian babies had suffered intrauterine growth retardation. In contrast the ratio of mid-arm circumference to occipitofrontal circumference did not differ significantly among the three groups (figure); $\mathbb{\mathbb { D }}$ 11 babies had values $>2$ SD below the mean and all showed evidence of wasting, though two had weights above the 10th percentile on standard 2 charts. Of the 64 neonates below the 10th percentile for weight, $20(32 \%)$ had $\%$ a ratio of mid-arm circumference to occipitofrontal circumference $>2$ SD $\overrightarrow{\vec{D}}$ below the mean (figure). Nine of these 21 infants developed symptoms: six had low blood glucose concentrations $(<2 \mathrm{mmol} / 1(<36 \mathrm{mg} / 100 \mathrm{ml}))$, seven had poor temperature control $\left(36^{\circ} \mathrm{C}\right)$, and one developed necrotising $\frac{\bar{F}}{\bar{\omega}}$ enterocolitis.

\section{Discussion}

Accurate identification of intrauterine growth retardation is $\overrightarrow{\vec{\omega}}$ important if complications such as early hypoglycaemia, poor $\stackrel{\circ}{\circ}$ temperature control, and sepsis are to be avoided. ${ }^{4}$ Many cities now $\frac{5}{3}$ have a multiethnic population, and the application of weight standards alone may be inappropriate. The ratio of mid-arm $\mathbb{N}$ circumference to occipitofrontal circumference has been used to $\dot{\sigma}$ indicate malnutrition in older children ${ }^{5}$; our study found that this $N$ ratio shows no intraethnic variation and can be used as a reliable and $:$ simple screening test to identify babies whose growth is retarded, $\overrightarrow{\mathscr{C}}$ even when their weight does not fall below the 10th percentile. 6 Those babies whose occipitofrontal circumference is reduced 을 because of proportionate growth retardation might not be identi- $\overrightarrow{0}$ fied, but they do not have the same risk of hypoglycaemia. Similarly, babies with hydrocephalus may give a falsely low reading.

\section{References}

1 Simmons $\mathrm{K}$, Savage $\mathbf{W}$, Nicholls $\mathbf{B}$, Rao U. Fetal growth measured by ultrasound in Bengali women. Foumal of Obstetrics and Gynaecology 1985;5:233-6.

Jore OG. Fetal growth in different racial groups. Arch Dis Child 1978.53. $27-32$

3 Clarson CL, Barher MJ, Marshall T, Wharton BA. Secular changes in birth weight of Asian babies born in Birmingham. Arch Dis Child 1982;57:867-71

4 Wallis S, Harvey D. Small-for-dates babies, after problems and their future. In: Wharton B, ed. $\overline{\overline{\mathbf{O}}}$ Topics in perinatal medicine. Tunbridge Wells: Pitman Medical, 1980.

5 Kanawati A, McLaren D. Assessment of marginal malnutrition. Nature 1970;228:573-4.

(Accepted 4 February 1986

\section{YEARS AGO}

"Sir,-Having read your learned discourse on the subject of the higher education of women, I beg, though rather late, to thank you, on my own behalf and that of my sex generally, for your very high opinion of us, as expressed at the meeting of the British Medical Association; though I must confess that it is somewhat new and startling to learn that women were created solely for the purpose of propagating the human species, and, as such, for the mere convenience of that glorious creature 'man,' as represented by your own illustrious self. It may perhaps be showing my great ignorance and inferiority when $\mathrm{I}$, as a woman, repudiate your highly flattering suggestions, and not only entirely and emphatically deny the truth of them (though you are such a very distinguished medical man), and assert that, having been created with an equal intellect as man's, and with an equal love of knowledge and independence, that in itself proves the utter fallacy of your disgusting theory. Of course, every one is aware that medical men are threatened with the loss of quite half of their practice by the admission of women into the profession, as their women patients would of course gladly give the preference to their own sex, when they have the opportunity; and as medical gentlemen are by no means indifferent to the question of pounds, shillings, and pence, it is not so much wonder that they express such horror at the prospect of their fat incomes being endangered. Though, however, on this account they may deserve some pity, yet that alone will not be sufficient to preserve them from the ridicule and contempt excited by their miserable efforts to exclude women from the medical profession, the sordid motive for doing so being too palpable. Therefore, before saying adieu, let me give you o one piece of advice, which is that, in your future opposition to the progress of $D$ women, not at any rate to repeat the disgusting, and insulting, and ignorant remarks on my sex, or else you may perhaps find by bitter experience that, $\bar{N}$ though women are, as you make them out to be, on a level with the beasts of $\mathrm{N}$ the field, they may yet be capable of showing their resentment at being told $\omega$ so by administering a sound chastisement on the offender, even though he may occupy the important position of President of the British Medicalo Association, or of any other ridiculous and trumpery association.-Your $\frac{}{\mathbb{Q}}$ obedient servant, (British Medical fournal 1886;ii:426.)

\section{Correction}

Synthesis of histamine by Haemophilus influenzae

We regret that an error occurred in this paper by Dr Bryan D Sheinman et al, 29 응 March, p 857. The second sentence of the abstract should have read: "Ten isolates of Haemophilus influenzae . . were incubated at $37^{\circ} \mathrm{C}$ for 48 hours," not "for 72 hours." 